\title{
Biocontrol Potential of Neem Leaf-Based Vermicompost as Indicated by Chitinase, Protease and $\beta-1,3-$ Glucanase Activity
}

(Potensi Biokawalan Vermikompos Berasaskan Daun Semambu seperti yang Ditunjukkan oleh Aktiviti Kitinase, Protease dan $\beta$-1,3-Glucanase)

\author{
LoH Khye ER, Nor AzWAdy Abdul AzIZ*, Muskhazli Mustafa \& InTAN SAFInAR Ismail
}

\section{ABSTRACT}

The rising concern regarding the negative impact of synthetic pesticides has led to the search for alternative means of pest control. Vermicomposting the mixture of oil palm empty fruit bunch and neem (Azadirachta indica) leaves, with the latter known to have pesticidal value, is therefore of great interest and significance to be studied. The present study was conducted to evaluate the chitinase, protease and $\beta$-1,3-glucanase activity of neem leaf-based vermicompost as an indication of its biocontrol properties. The total microbial population of different composition of the vermicompost was also investigated. The results showed that at 10\% neem composition, an increment in microbial population, chitinase and protease activities was observed in the end product. A higher concentration of neem exerted a suppressive effect on the microbial population as well as enzymatic activity. This study suggested that the addition of an appropriate composition of neem leaves as one of the raw materials for vermicomposting would potentially enhance the performance of vermicompost as biofertilizer as well as biopesticide.

Keywords: Biopesticide; chitinase; neem leaf; protease; $\beta$-1,3-glucanase

\section{ABSTRAK}

Kebimbangan yang semakin meningkat mengenai kesan negatif racun perosak sintetik telah menyebabkan pencarian kaedah alternatif kawalan perosak. Oleh itu, pengkomposan campuran tandan buah kosong kelapa sawit dan daun semambu (Azadirachta indica) yang diketahui mempunyai nilai racun perosak telah menarik perhatian dan lebih bermakna untuk dikaji. Kajian ini dilakukan untuk menilai aktiviti kitinase, protease dan $\beta$-1,3-glukanase vermikompos yang berasaskan daun semambu sebagai petunjuk sifat biokawalannya. Jumlah populasi mikroorganisma bagi vermikompos yang berbeza daripada segi komposisinya juga telah dikaji. Hasil kajian menunjukkan peningkatan populasi mikroorganisma, aktiviti kitinase dan protease pada produk akhir yang mempunyai $10 \%$ daun semambu. Kepekatan semambu yang lebih tinggi memberi kesan penindasan terhadap populasi mikroorganisma dan juga aktiviti enzim. Kajian ini mencadangkan bahawa penambahan komposisi daun semambu yang sesuai sebagai salah satu bahan mentah untuk pengkomposan berpotensi meningkatkan prestasi vermikompos sebagai baja dan racun perosak biologi.

Kata kunci: Daun semambu; kitinase; protease; racun perosak biologi; $\beta$-1,3-glukanase

\section{INTRODUCTION}

The rising concern regarding the negative impact of synthetic pesticides has led to an urgent need for a more organic way of pest control. It has been reported that the application of organic matter to soils can reduce arthropod pests' population. Farmers have indicated that plants grown with organic fertilizers or pesticides are more resistant to diseases and pests (Yardim \& Edwards 2003).
Vermicompost is a nutrient rich biofertilizer obtained in organic matter recycling. It is well known for its rich content of available nutrients, such as nitrates, phosphorus, potassium, calcium and magnesium that is readily absorbed by plants (Mistry et al. 2015). Vermicompost is also rich in beneficial microorganisms and soil enzymes. The action of microorganisms and enzymes is essential for the sustainable release of nutrients, thereby reducing the 
negative impacts of synthetic soil amendments to the environment (Uz \& Tavali 2014).

According to Pathma and Sakthivel (2012), vermicompost can also be used as biopesticides in suppressing plant pathogens and plant parasitic nematodes. The effects of vermicompost on the suppression of soil-borne diseases are likely due to both biological and chemical factors. Biological factors are mainly attributed to the action of the microbial community inhabiting the composts. The combined action of earthworms and microorganisms favor the increase in microbial population density and biodiversity, and subsequently the enzymatic activities in vermicompost (Macci et al. 2010). During the entire process of vermicomposting, different types of hydrolytic enzymes which aid in the biodegradation of the organic wastes are produced. The microorganisms cast from earthworm's gut can digest a broad range of organic materials, including cellulose, chitin, lignin and polylactic acids (Vivas et al. 2009).

Hydrolytic enzymes that are capable of hydrolyzing fungal cell wall components are known to possess mycoparasitism, in which some examples of important mycoparasitic enzymes are protease, chitinase and $\beta-1,3-$ glucanase (Jadhav \& Sayyed 2016). Fungal cell wall is composed of polymers, such as mannans, glucans and chitin. It is an important barrier protecting the microorganism from the attack of other microorganisms or against the harsh environment. Some well-known biocontrol agents digest phytopathogen cell wall by excreting hydrolases, such as protease, cellulase, $\beta-1,3-$ glucanase and chitinase (Jadhav \& Sayyed 2016). Therefore, utilizing materials known to possess pesticidal value as part of the vermicomposting material on top of the antifungal hydrolytic enzymes present in vermicompost could potentially enhance its function as biofertilizercum-biopesticide.

Neem tree (Azadirachta indica) belongs to the family of Meliaceae. These trees can be found in subtropical regions and are native to countries like India and Asia. Neem can serve as an excellent fertilizer because it is nutrient rich (Lokanadhan et al. 2012). Previous work showed that the addition of neem leaves as one of the raw materials in vermicomposting enriches the nutrient, such as nitrogen, phosphorus, potassium and calcium content of the end product (Loh et al. 2012). Parts of the neem tree, such as seeds and leaves, contain an active ingredient known as azadirachtin, which has insecticidal, fungicidal, bactericidal, and nematicidal properties (Chaudhary et al. 2017; Gajalakshmi \& Abbasi 2004; Gopal et al. 2007). To date, there are limited studies exploring neem leaves as a substrate for vermicomposting despite its nutritional value due to the fact that it might kill the earthworms.

In addition to that, the negative impacts of synthetic fertilizers and pesticides have shifted the interests of researchers towards organic amendments like vermicompost as biofertilizer and biocontrol agents without polluting the environment. To bridge this knowledge gap, this study was conducted to analyze chitinase, protease and $\beta-1,3-$ glucanase activities as well as to determine the microbial population in neem leaf-based vermicompost.

\section{Materials AND Methods}

\section{EARTHWORMS AND WASTE MATERIALS}

Adult Eudrilus eugeniae of about the same size (about $1 \mathrm{~g})$ were randomly selected from the vermibed of the Vermiculture Laboratory, Department of Biology, Universiti Putra Malaysia (UPM). Empty fruit bunch was collected from a palm oil mill (Dengkil, Selangor). Neem leaves were collected from UPM campus and was identified by Dr. Mohd. Firdaus Ismail at the Biodiversity Unit, Institute of Bioscience, UPM and a voucher specimen (SK3139/17) was deposited in the herbarium of that institute. Cow manure was collected from Taman Pertanian Universiti, UPM. The neem leaves, empty fruit bunch and cow manure were air dried, ground into small particles and sieved through a $2 \mathrm{~mm}$ sieve.

\section{EXPERIMENTAL SETUP}

Round plastic containers ( $3 \mathrm{~L}$ ) were used in this experiment. A total of $250 \mathrm{~g}$ (dry weight) of raw materials were thoroughly mixed to produce different ratios of vermibeds (Table 1). All mixtures were subjected to $20 \%$ cow dung as food supplement to the worms. This is to ensure that vermicomposting is conducted under ambient conditions, as cow dung is needed for optimum worm growth and is essential for microbial decomposition of organic wastes (Palta \& Bhatnagar 2007). The substrates were incubated for four weeks at $80 \%$ moisture content by periodic sprinkling of distilled water for thermal stabilization, and were turned occasionally to allow aeration. Approximately $6.25 \mathrm{~g}$ of adult Eudrilus eugeniae was then inoculated into each container. The vermibins were covered with a net and placed in a laboratory with a temperature of $25-27{ }^{\circ} \mathrm{C}$. The substrates were vermicomposted for 60 days. For each treatment, control treatment (compost without worms) was also prepared in a similar setup $(n=4)$. After 2 months, watering was stopped. Fresh and moist vermicomposts and composts were sampled randomly for enzymatic and microbiological analyses. 
TABLE 1. Composition of waste materials used in vermibeds

\begin{tabular}{ll}
\hline Treatments & \multicolumn{1}{c}{ Descriptions } \\
\hline VC1 & $40 \%$ neem leaves : $40 \%$ empty fruit bunch : $20 \%$ cow dung + earthworms \\
C1 & $40 \%$ neem leaves : $40 \%$ empty fruit bunch : $20 \%$ cow dung \\
VC2 & $20 \%$ neem leaves : $60 \%$ empty fruit bunch : $20 \%$ cow dung + earthworms \\
C2 & $20 \%$ neem leaves : $60 \%$ empty fruit bunch : $20 \%$ cow dung \\
VC3 & $10 \%$ neem leaves : $70 \%$ empty fruit bunch : $20 \%$ cow dung + earthworms \\
C3 & $10 \%$ neem leaves : $70 \%$ empty fruit bunch : $20 \%$ cow dung \\
VC4 & $80 \%$ empty fruit bunch : $20 \%$ cow dung + earthworms \\
C4 & $80 \%$ empty fruit bunch : $20 \%$ cow dung \\
VC5 & $100 \%$ empty fruit bunch + earthworms \\
C5 & $100 \%$ empty fruit bunch \\
\hline
\end{tabular}

VC: Vermicomposting, C: control

\section{CHITINASE ACTIVITY ANALYSIS}

Chitinase activity was determined by using fluorogenic substrate, 4-methylumbeliferyl- $N$ acetyl- $\beta$-d-glucosaminide (Sigma), which measures 4-methylumbeliferone (4MU) released because of hydrolysis (Poulsen et al. 2008). The vermicomposts/ composts $(20 \mathrm{mg} / \mathrm{mL})$ were suspended in $50 \mathrm{mM}$ Trismalate buffer ( $\mathrm{pH} 5$ ) and vortexed for $10 \mathrm{~s}$. The assay was carried out in replication of four for each treatment. The chitinase activity was measured using a fluorometer (LS 55 Fluorescence Spectrometer, Perkin Elmer) at $377 \mathrm{~nm}$ excitation and $446 \mathrm{~nm}$ emission. Chitinase activity was determined from a standard curve obtained from 4MU and was expressed as nmole 4MU liberated per g (dry weight) of sample per hour.

\section{PROTEASE ACTIVITY ANALYSIS}

Casein (Sigma) was used for the quantification of protease activity (Ladd \& Butler 1972). Protease activity was measured at $700 \mathrm{~nm}$ using a spectrophotometer (U-1900 Spectrophotometer, Hitachi). The assay was replicated four times and the activity was determined from a standard curve obtained from tyrosine (Merck). Protease activity was expressed as $\mu$ mole tyrosine liberated per gram (dry weight) of sample per hour.

\section{B-1,3-GLUCANASE ACTIVITY ANALYSIS}

$\beta-1,3$-glucanase activity was determined using the modified method of Chae et al. (2006), which measures glucose released as the result of laminarin (Sigma) digestion $(\mathrm{n}=4)$. $\beta-1,3$-glucanase activity was measured at $550 \mathrm{~nm}$ using a spectrophotometer (U-1900 Spectrophotometer, Hitachi) and calculated from a glucose (Aldrich) standard curve. The activity was defined as $\mu$ mole glucose liberated per gram (dry weight) of sample per hour.

\section{MICROBIAL POPULATION DENSITY DETERMINATION}

Drop plate method (Herigstad et al. 2001) was used to determine the microbial population density. Serial dilutions $\left(10^{-1}-10^{-7}\right)$ of the sample suspension were prepared. Dilutions $10^{-2}-10^{-5}$ were used for the estimation of fungi population, dilutions $10^{-3}-10^{-6}$ were used for the estimation of actinomycetes' population, and dilutions $10^{-4}-10^{-7}$ were used for the estimation of bacteria population. Rose Bengal agar (RBA), Nutrient agar (NA) and Actinomycete agar (AA) were used for isolating fungi, bacteria, and actinomycetes, respectively. For drop plating, $10 \mu \mathrm{L}$ of dilutions were pipetted and expelled onto the plate immediately after vortex. All plates were incubated at room temperature $\left(25-27^{\circ} \mathrm{C}\right)$ for $1-2$ days for bacteria, and 5-7 days for fungi and actinomycetes. Viable cell counts are expressed as $\log _{10}$ colony forming unit (cfu) per $\mathrm{g}$ of dry compost. 


\section{STATISTICAL ANALYSIS}

For statistical analysis, SPSS (Statistical Package for Social Sciences), version 17.0 was used. The data obtained was analyzed using One-way Analysis of Variance (ANOVA), Duncan post hoc test and Pearson's correlation at significance level of 0.05 .

\section{RESULTS AND DISCUSSION}

The present study showed that the addition of 10 and $20 \%$ neem enhanced the total microbial population density, but the addition of $40 \%$ neem significantly suppressed the microbial population in both $\mathrm{VCl}$ and $\mathrm{C} 1$ (Table 2). Previous studies have reported the anti-microbial and anti-fungal properties of azadirachtin in neem (Coventry \& Allan 2001; Govindachari et al. 2000). Therefore, the addition of neem leaves at a certain level might suppress the microorganisms or fungi in vermicompost. A study by Gopal et al. (2007) suggested that neem seed kernel extract reduces bacterial and fungal populations significantly, in which azadiractin being the main active ingredient of the extract.
However, the consistent increase in bacteria, actinomycetes and fungal population densities observed in the vermicompost with $10 \%$ neem leaf indicated that neem leaf, at $10 \%$ composition, is palatable to earthworms and favorable for microorganisms' growth. Neem leaf, which is well known as a powerful nematicide, has been shown to increase the growth and reproduction of Eudrilus eugineae (Gajalakshmi \& Abbasi 2004). The action of earthworm could be the factor that contributes to the higher bacteria, actinomycetes and fungi population density demonstrated in T2 and T3 vermicompost in the present study. This may be due to neem leaf is nutrient rich (Lokanadhan et al. 2012), thereby increasing the microbial activity in earthworm gut and its vermicasts despite its antimicrobial activity. In addition to that, earthworm guts maintain a favorable condition for microorganisms, resulting in greater microbial activity, plant growth factors and pest repellants in the vermicasts produced. Bacteria that help in food digestion are found in the foregut, actinomycetes that are antagonistic against pathogens are found in the midgut, and fungi that help in the formation of vermicast are found in the hindgut (Kiyasudeen et al. 2014).

TABLE 2. Bacteria, actinomycete, fungi and total microbial population density $\left(\log _{10}\right.$ cfug $\left.^{-1}\right)$ in vermicompost and control of different treatments. Values are mean \pm standard error of the mean $(n=4)$

\begin{tabular}{ccccccccc}
\hline & \multicolumn{2}{c}{ Bacteria } & \multicolumn{2}{c}{ Actinomycetes } & \multicolumn{2}{c}{ Fungi } & \multicolumn{2}{c}{ Total } \\
\cline { 2 - 8 } & $\mathrm{VC}$ & $\mathrm{C}$ & $\mathrm{VC}$ & $\mathrm{C}$ & $\mathrm{VC}$ & $\mathrm{C}$ & $\mathrm{VC}$ & $\mathrm{C}$ \\
\hline $\mathrm{T} 1$ & $0.00 \pm$ & $7.58 \pm$ & $8.21 \pm$ & $7.53 \pm$ & $5.96 \pm$ & $5.94 \pm$ & $14.17 \pm$ & $21.05 \pm$ \\
& $0.00^{\mathrm{Bd}}$ & $0.09^{\mathrm{Ab}}$ & $0.05^{\mathrm{Aab}}$ & $0.04^{\mathrm{Bab}}$ & $0.03^{\mathrm{Ac}}$ & $0.03^{\mathrm{Ac}}$ & $0.04^{\mathrm{Bd}}$ & $0.10^{\mathrm{Ab}}$ \\
$\mathrm{T} 2$ & $8.84 \pm$ & $7.67 \pm$ & $8.21 \pm$ & $7.59 \pm$ & $6.53 \pm$ & $6.37 \pm$ & $23.59 \pm$ & $21.62 \pm$ \\
& $0.02^{\mathrm{Aa}}$ & $0.14^{\mathrm{Bb}}$ & $0.05^{\mathrm{Aab}}$ & $0.04^{\mathrm{Bab}}$ & $0.05^{\mathrm{Aa}}$ & $0.02^{\mathrm{Ba}}$ & $0.03^{\mathrm{Aa}}$ & $0.14^{\mathrm{Bab}}$ \\
$\mathrm{T} 3$ & $8.62 \pm$ & $7.79 \pm$ & $8.25 \pm$ & $7.61 \pm$ & $6.42 \pm$ & $6.20 \pm$ & $23.29 \pm$ & $21.60 \pm$ \\
& $0.06^{\mathrm{Aa}}$ & $0.12^{\mathrm{Bb}}$ & $0.02^{\mathrm{Aa}}$ & $0.01^{\mathrm{Bab}}$ & $0.05^{\mathrm{Aa}}$ & $0.06^{\mathrm{Bb}}$ & $0.11^{\mathrm{Aa}}$ & $0.12^{\mathrm{Bab}}$ \\
$\mathrm{T} 4$ & $7.55 \pm$ & $7.64 \pm$ & $7.97 \pm$ & $7.52 \pm$ & $5.85 \pm$ & $6.10 \pm$ & $21.37 \pm$ & $21.26 \pm$ \\
& $0.12^{\mathrm{Ac}}$ & $0.09^{\mathrm{Ab}}$ & $0.03^{\mathrm{Ab}}$ & $0.03^{\mathrm{Bb}}$ & $0.07^{\mathrm{Bc}}$ & $0.06^{\mathrm{Ab}}$ & $0.10^{\mathrm{Ac}}$ & $0.07^{\mathrm{Ab}}$ \\
\hline & $8.40 \pm$ & $8.11 \pm$ & $8.06 \pm$ & $7.75 \pm$ & $6.16 \pm$ & $6.24 \pm$ & $22.62 \pm$ & $22.10 \pm$ \\
\hline
\end{tabular}

T1: 40\%N:40\%EFB:20\%CD, T2: 20\%N:60\%EFB:20\%CD, T3: 10\%N:70\%EFB:20\%CD, T4: $80 \%$ EFB:20\%CD, T5: $100 \%$ EFB, VC: vermicompost, C: control. Means with different uppercase letter (horizontal comparison between $\mathrm{VC}$ and $\mathrm{C}$ ) and different lowercase letter (vertical comparison) showed significant difference $(\mathrm{p}<0.05)$ 
The chitinase activity was higher in vermicompost (VC) than the control (C), except in VC5 (Figure 1). In vermicompost, VC3 (10\% neem) showed the highest chitinase activity, followed by VC4 (0\% neem, 80\% EFB: $20 \%$ CD), VC2 (20\% neem) and VC1 (40\% neem). The higher chitinase activity in the vermicompost was most probably contributed by the chitinolytic activity of actinomycetes present in the earthworm gut and vermicompost. This is supported by the positive relationship $(\mathrm{r}=0.571, \mathrm{p}<0.01)$ between the chitinase activity and the actinomycetes' population density demonstrated in this study. According to Yasir et al. (2009), chitinase gene diversity is increased by the action of earthworm via the enrichment of chitinolytic bacteria in vermicompost. In general, earthworm uses fungi as a food source. Since the cell wall of fungi is made of chitin, the feeding activity of earthworms and their excretion of casts are enriched with chitin-decomposing microorganisms and enzymes. This subsequently contributes to the higher chitinase activities in vermicompost (Devi et al. 2009).

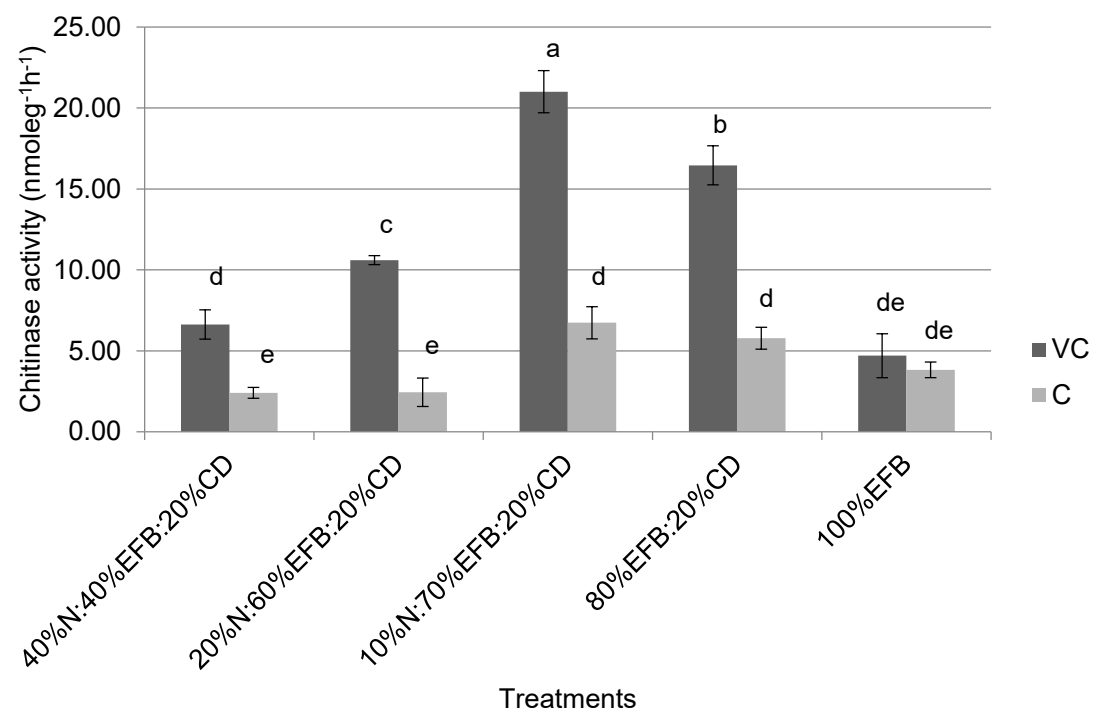

FIGURE 1. Chitinase activity in vermicompost (VC) and control (C) of different treatments. Values are mean \pm standard error of the mean. Different letter showed significant difference $(\mathrm{p}<0.05), \mathrm{n}=4$

In contrast, protease activity was lower in $\mathrm{VC}$ than $\mathrm{C}$ (Figure 2). The protease activity was highest in $\mathrm{C} 3$ ( $10 \%$ neem), followed by $\mathrm{C} 4$ ( $0 \%$ neem, $80 \%$ EFB: $20 \% \mathrm{CD})$ and $\mathrm{C} 2$ (20\% neem), and the lowest activity was in $\mathrm{C} 1$ (40\% neem) and C5 (0\% neem, 100\% EFB), respectively. The low protease activity in vermicompost might be caused by the depletion of protein content during vermicomposting. According to Aira et al. (2006), earthworms exploit the organic carbon and nitrogen pools in vermicompost during vermicomposting. The depletion of available organic substrates subsequently decreases the enzyme synthesis by microorganisms (Garcia et al. 1994). Our result is in agreement with Lazcano et al. (2008), in which the earthworm-free compost has higher protease activity than the treatments with earthworms. The low protease activity in vermicompost could be attributed to the dependency of enzyme activity on substrate availability. A study by Devi et al. (2009) demonstrated that caseinhydrolysing protease activity declines sharply as protein content decreases in the ageing substrate.

Additionally, protease activity has a positive relationship with microbial population density $(r=0.321$, 
$\mathrm{p}<0.05)$. Though prematurely, the result suggested that microorganisms might play a part in affecting the patterns of protease activity. The result of this study corroborates the finding by Benitez et al. (2002), in which significant correlations between protease activity and microbial population density were observed. Together with enzyme activity decline, the progressive deficient in substrate also reduces the microbial population density, which affects the synthesis of new enzymes. This explains the dependency of the microbial population and protease activity on substrate availability.

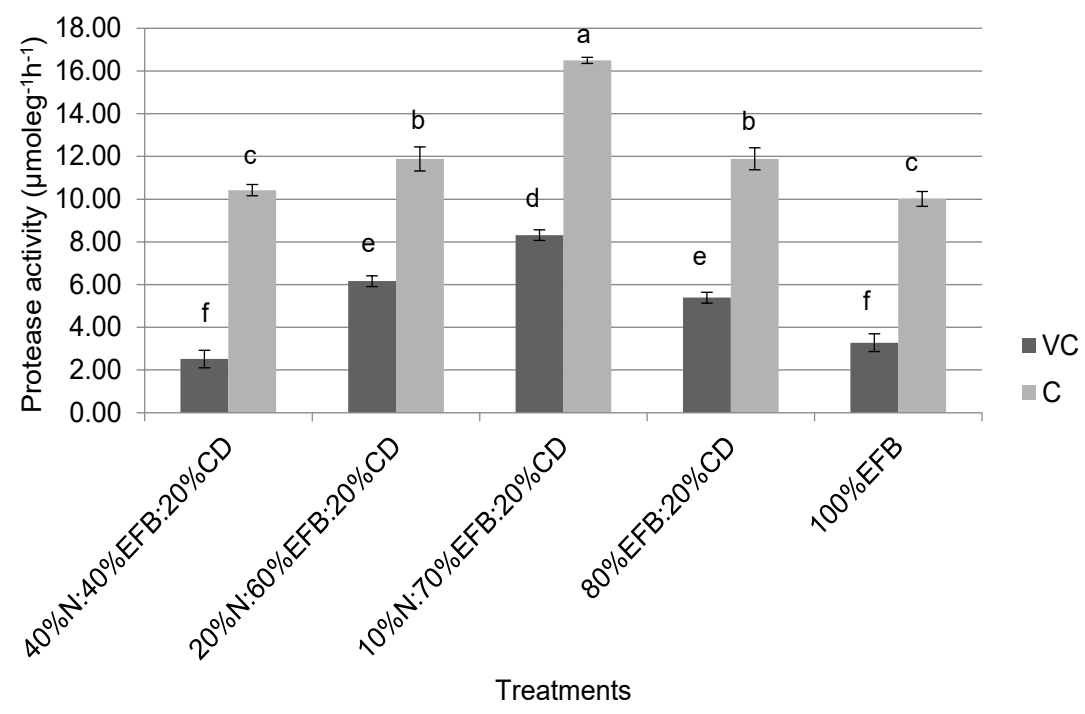

FIGURE 2. Protease activity in vermicompost (VC) and control (C) of different treatments. Values are mean \pm standard error of the mean. Different letter showed significant difference $(\mathrm{p}<0.05), \mathrm{n}=4$

From the results, $\beta$-1,3-glucanase activity did not show any clear pattern as the case for chitinase and protease (Figure 3). Our results demonstrated that $\mathrm{VC1}$ and VC5 possessed higher $\beta$-1,3-glucanase activity than that of their controls, whereas $\mathrm{VC} 2, \mathrm{VC} 3$ and VC4 were not significantly different from their controls. This indicated that the active ingredient in neem leaf might not have any significant effect on $\beta$-1,3-glucanase activity, as no clear pattern was recorded for this enzyme. To understand the activity of $\beta$-1,3-glucanase enzyme, its relationship with other enzymes was analyzed by conducting Pearson correlation analysis. The results showed that the $\beta-1,3-$ glucanase activity has a negative relationship with protease activity $(\mathrm{r}=-0.468, \mathrm{p}<0.01)$. The negative correlation suggested that the former was probably suppressed by the latter. According to Pitson et al. (1996), the presence of protease inactivates one of the three extracellular $\beta-1,3-$ glucanase activities produced by a filamentous fungus Acremonium persicinum at neutral or alkaline medium $\mathrm{pH}$. The $\mathrm{pH}$ of vermicompost usually falls in the range of neutral to alkaline (Padmavathiamma et al. 2008), and the $\mathrm{pH}$ range for protease activity was observed at 7.0 to 9.2 with an optimum pH7.8 (Akel et al. 2009). This phenomenon could contribute to an increase in protease activity, which in turn inactivates the $\beta$-1,3-glucanase produced by the microorganisms. 


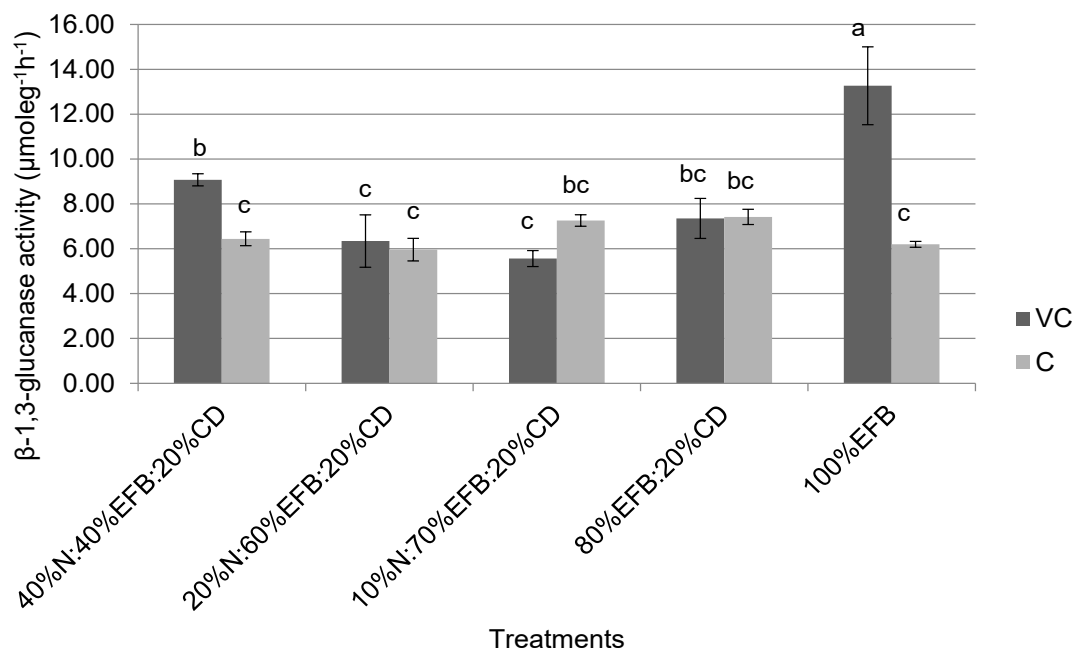

FIGURE 3. $\beta$-1,3-glucanase activity in vermicompost (VC) and control (C) of different treatments. Values are mean \pm standard error of the mean. Different letter showed significant difference $(\mathrm{p}<0.05), \mathrm{n}=4$

The present study showed that treatment with $10 \%$ neem resulted in the highest chitinase and protease activity in both vermicompost and control. However, a decrease in enzyme activity was observed at higher neem composition. The pattern of enzyme activity coincides with the microbial population density. This indicated that neem composition plays a major role in determining the microbial population density, and subsequently the enzymatic activity of the vermicompost. In this context, the active ingredients introduced by the addition of neem affects the biocontrol properties of the vermicompost indirectly via the action of earthworms. The findings suggested that there is a threshold level (about 20\% neem) at which the microorganisms can withstand the bioactivity of compounds introduced by the addition of neem leaves, with $10 \%$ neem being the most suitable composition for the enhancement of microbial and enzyme activity in vermicompost. According to Gopal et al. (2007), the application of azadirachtin granules into soil at a recommended dose has an enhancing effect on the microbial population density and enzyme activity, whereas higher doses would give a negative impact. The reason could be that the enhanced microbial population subsequently contributed to the increase in the enzymes' activity in vermicompost.

\section{CONCLUSION}

Our study suggested that the addition of an appropriate composition (10\%) of neem leaf as one of the raw materials in vermicompost would enhance the microbial population and increase the chitinase and protease activities, which are important fungus-controlling enzymes. Thus, further study on the biopesticide value of the neem leaf-based vermicompost is worth being carried out by conducting bioassays on certain insect pests of economic importance or by identifying the bioactive compounds present in the vermicompost.

\section{ACKNOWLEDGEMENTS}

The present study was financially supported by Putra Grant, Universiti Putra Malaysia, project number GP/2017/9568300. This study was carried out at the Department of Biology, Faculty of Science, Universiti Putra Malaysia.

\section{REFERENCES}

Aira, M., Monroy, F. \& Dominguez, J. 2006. Eisenia fetida (Oligochaeta, Lumbricidae) activates fungal growth, triggering cellulose decomposition during vermicomposting. Microbial Ecology 52(4): 738-747. 
Akel, H., Al-Quadan, F. \& Yousef, T.K. 2009. Characterization of a purified thermostable protease from hyperthermophilic Bacillus strain HUTBS71. European Journal of Scientific Research 31(2): 280-288.

Benitez, E., Sainz, H., Melgar, R. \& Nogales, R. 2002. Vermicomposting of a lignocellulosic waste from olive oil industry: A pilot scale study. Waste Manage \& Research 20(2): 134-142.

Chae, D.H., Jin, R.D., Hwangbo, H., Kim, Y.W., Kim, Y.C., Park, R.D., Krishnan, H.B. \& Kim, K.Y. 2006. Control of late blight (Phytophthora capsici) in pepper plant with a compost containing multitude of chitinase-producing bacteria. BioControl 51: 339-351.

Chaudhary, S., Kanwar, R.K., Sehgal, A., Cahill, D.M., Barrow, C.J., Sehgal, R. \& Kanwar, J.R. 2017. Progress on Azadirachta indica based biopesticides in replacing synthetic toxic pesticides. Frontiers in Plant Science 8: 610.

Coventry, E. \& Allan, E.J. 2001. Microbial and chemical analysis of neem (Azadirachta indica): Notes on antimicrobial activity. Phytoparasitica 29: 441-450.

Devi, S.H., Vijayalakshmi, K., Jyotsna, K.P., Shaheen, S.K., Jyothi, K. \& Rani, M.S. 2009. Comparative assessment in enzyme activities and microbial populations during normal and vermicomposting. Journal of Environmental Biology 30(6): 1013-1017.

Gajalakshmi, S. \& Abbasi, S.A. 2004. Neem leaves as a source of fertilizer-cum-pesticide vermicompost. Bioresource Technology 92(3): 291-296.

Garcia, C., Hernandez, T., Costa, F. \& Ceccanti, B. 1994. Biochemical parameters in soils regenerated by addition of organic wastes. Waste Management \& Research 12(6): 457-466.

Gopal, M., Gupta, A., Arunachalam, V. \& Magu, S.P. 2007. Impact of azadirachtin, an insecticidal allelochemical from neem on soil microflora, enzyme and respiratory activities. Bioresource Technology 98(16): 3154-3158.

Govindachari, T.R., Suresh, G., Geetha Gopalakrishnan, Masilamani, S. \& Banumathi, B. 2000. Antifungal activity of some tetratriterpenoids. Fitoterapia 71(3): 317-320.

Herigstad, B., Hamilton, M. \& Heersink, J. 2001. How to optimize the drop plate method for enumerating bacteria. Journal of Microbiological Methods 44(2): 121-129.

Jadhav, H.P. \& Sayyed, R.Z. 2016. Hydrolytic enzymes of rhizospheric microbes in crop protection. MedCrave Online Journal of Cell Science \& Report 3(5): 135-136.

Kiyasudeen, K., Jessy, S.R.S. \& Ibrahim, M.H. 2014. Earthworm's gut as reactor in vermicomposting process: A mini review. International Journal of Scientific and Research Publications 4(7): 1-6.

Ladd, J.N. \& Butler, J.H. 1972. Short-term assays of soil proteolytic enzyme activities using proteins and dipeptide derivitives as substrates. Soil Biology and Biochemistry 4(1): 19-30.

Lazcano, C., Gomez-Brandon, M. \& Dominguez, J. 2008. Comparison of the effectiveness of composting and vermicomposting for the biological stabilization of cattle manure. Chemosphere 72(7): 1013-1019.

Loh, K.E., Aziz, N.A.A., Kok, H.Y., Mustafa, M., Ismail, I.S. \& Zainudin, N.A.I.M. 2012. Potential of neem leaf-empty fruit bunch-based vermicompost as biofertiliser-cumbiopesticide: Chemical properties, humic acid content and enzymes (protease and phosphatase) activity in vermicompost (Part I). Scientific Research and Essays 7(42): 3657-3664.

Lokanadhan, S., Muthukrishnan, P. \& Jeyaraman, S. 2012. Neem products and their agricultural applications. Journal of Biopesticides 5(Supplementary): 72-76.

Macci, C., Masciandaro, G. \& Ceccanti, B. 2010. Vermicomposting of olive oil mill wastewaters. Waste Management \& Research 28(8): 738-747.

Mistry, J., Mukhopadhyay, A.P. \& Baur, G.N. 2015. Status of N P K in vermicompost prepared from two common weed and two medicinal plants. International Journal of Applied Sciences and Biotechnology 3(2): 193-196.

Padmavathiamma, P.K., Loretta, Y.L. \& Kumari, U.R. 2008. An experimental study of vermi-biowaste composting for agriculture soil improvement. Bioresource Technology 99(6): 1672-1681.

Palta, R.K. \& Bhatnagar, R.K. 2007. Vermiculture: A technology to manage solid wastes. In Earthworms for Solid Waste Management, edited by Singh, S.M. India, International Book Distributing Co. pp. 17-50.

Pathma, J. \& Sakthivel, N. 2012. Microbial diversity of vermicompost bacteria that exhibit useful agricultural traits and waste management potential. Springerplus 1: 26.

Pitson, S.M., Seviour, R.J. \& Mcdougall, B.M. 1996. Proteolytic inactivation of an extracellular $(1 \rightarrow$ $3)-\beta$-glucanase from the fungus Acremonium persicinum is associated with growth at neutral or alkaline medium $\mathrm{pH}$. FEMS Microbiology Letters 145(2): 287-293.

Poulsen, P.H.B., Moller, J. \& Magid, J. 2008. Determination of a relationship between chitinase activity and microbial diversity in chitin amended compost. Bioresource Technology 99(10): 4355-4359.

Uz, I. \& Tavali, I.E. 2014. Short-term effect of vermicompost application on biological properties of an alkaline soil with high lime content from Mediterranean region of Turkey. The Scientific World Journal 2014: 1-11.

Vivas, A., Moreno, B., Garcia-Rodiguez, S. \& Benitez, E. 2009. Assessing the impact of composting and vermicomposting on bacterial community size and structure, and microbial functional diversity of an olive-mill waste. Bioresource Technology 100(3): 1319-1326.

Yardim, E.N. \& Edwards, C.N. 2003. Effects of organic and synthetic fertilizer sources on pest and predatory insects associated with tomatoes. Phytoparasitica 31(4): 324-329.

Yasir, M., Aslam, Z., Kim, S.W., Lee, S.W., Jeon, C.O. \& Chung, Y.R. 2009. Bacterial community composition and chitinase gene diversity of vermicompost with antifungal activity. Bioresource Technology 100(19): 4396-4403. 
Loh Khye Er

Department of Bioscience, Faculty of Applied Sciences Tunku Abdul Rahman University College

Jalan Genting Kelang Setapak

53300 Kuala Lumpur, Federal Territory

Malaysia

Nor Azwady Abdul Aziz* \& Muskhazli Mustafa

Department of Biology, Faculty of Science

Universiti Putra Malaysia

43400 UPM Serdang, Selangor Darul Ehsan

Malaysia
Intan Safinar Ismail

Department of Chemistry, Faculty of Science

Universiti Putra Malaysia

43400 UPM Serdang, Selangor Darul Ehsan

Malaysia

*Corresponding author; email: azwady@upm.edu.my

Received: 20 May 2020

Accepted: 7 October 2020 